tenci, nie zmienią swoich przyzwyczajeń. Wkrótce jednak ten proces nastąpi, zapewne szybciej w instytucjach państwowych aniżeli w archiwach, zatem problem przechowywania dokumentacji jest równie palący w tym aspekcie, dlatego warto dyskutować na tego typu tematy. Jednakże można odnieść wrażenie, że pomimo upływającego czasu, zmieniających się technologii, programów, języków programowania, problematyka komputeryzacji archiwów i dyskusje wokół tego problemu stoją w miejscu, co skutkuje raczej piętrzeniem się problemów związanych z dokumentacją elektroniczną niż rozwiązywaniem kolejnych trudności.

Magdalena Niedźwiedzka

(Uniwersytet Pedagogiczny im. KEN w Krakowie)

\title{
Z PROBLEMATYKI ARCHIWÓW PRYWATNYCH I RODZINNYCH
}

http://dx.doi.org/10.12775/AKZ.2014.013

$\mathbb{W}$ trakcie drugiej już konferencji organizowanej wspólnie przez Archiwum Państwowe w Poznaniu oraz Zakład Archiwistyki Instytutu Historii UAM wygłoszono 12 referatów związanych z problematyką archiwów prywatnych i rodzinnych. Sala im. Jerzego Topolskiego w IH UAM w Poznaniu przy ul. św. Marcin 3 października 2014 r. zgromadziła nie tylko wielu doskonałych teoretyków tematu, ale również praktyków i użytkowników archiwów (tak iż w sali nieomal brakło krzeseł), z czego radości nie kryła prof. Irena Mamczak-Gadkowska (Zakład Archiwistyki IH) otwierająca konferencję. Rad był również mgr Henryk Krystek (AP Poznań), szukając powodów dla tak licznie zgromadzonego audytorium: „Wszak wszyscy mamy swoje archiwa prywatne w domach!" - mówił, witając gości.

Organizatorzy podzielili spotkanie na trzy sesje z przerwą obiadową po drugiej. Pierwszej sesji przewodniczyła dr Magdalena Biniaś-Szkopek z IH UAM. Jako pierwszy swój referat wygłosił dr hab. Rafał Galuba (UAM) pt. Archiwa i archiwalia prywatne w polskim prawie archiwalnym. W wystąpieniu Galuba przeanalizował najważniejsze założenia dekretów z 1919 i 1951 r. oraz ustawy z 1983 r. Jego zdaniem ocena wartości dokumentacji wytwarza- 
nej w państwowych instytucjach nie powinna wynikać jedynie z ich statusu, ale winna być oceniana indywidualnie. W przeciwnym razie, jak podkreślał, duża część dokumentacji o wartości historycznej zostanie bezpowrotnie zniszczona. Następnie Anna Belka z NDAP w swoim wystąpieniu zatytułowanym Archiwa rodzinne w polityce Naczelnej Dyrekcji Państwowej zaprezentowała kampanie społeczne realizowane obecnie przez NDAP na rzecz zachowania dziedzictwa narodowego. Jako trzecia swój referat prezentowała prof. Wiesława Kwiatkowska. Profesor z Uniwersytetu Mikołaja Kopernika w Toruniu mówiła o trudnościach metodycznych i o wyzwaniach, jakie niesie za sobą opracowywanie, jak przyznała, najtrudniejszych w tym względzie, archiwów podworskich. W wystąpieniu zatytułowanym Metodyka i problemy opracowania archiwaliów rodzinnych prelegentka omówiła przepisy metodyczne z 1953 i 1983 r., które faworyzowały podczas opracowywania model rekonstrukcji zasobu, dopuszczając jednocześnie, w przypadku napotkania trudności, zastosowanie układu rzeczowego. Referat Marty Bednarovej i Zuzany Kollarovej z Archiwum Państwowego w Lewoczy - Odział w Popradzie omawiał aktualną sytuację prawną archiwów prywatnych na Słowacji.

Wystąpienie kolejnego gościa z zagranicy rozpoczęło drugą część obrad. Aleksander Stefanowicz z Biblioteki Naukowej Białoruskiej Akademii Nauk w Mińsku przedstawił cenne archiwalia polskie proweniencji prywatnej w zasobie tejże biblioteki, których jednak spora część pochodzi z fragmentów dawnej Biblioteki Wróblewskich z Wilna. Kolejnym wystąpieniem sekcji, której przewodniczył dr hab. Waldemar Chorążyczewski (UMK), był referat prof. Krzysztofa Stryjkowskiego z Uniwersytetu im. Adama Mickiewicza. W arcyciekawej prezentacji profesor przekonywał, iż rodzimy program NDAP dotyczący archiwów prywatnych powinien odwoływać się do wzorców kanadyjskich. W referacie pt. Kanadyjskie inicjatywy budowania i zachowania archiwów rodzinnych Stryjkowski omówił działania rozwijające świadomość zachowania archiwaliów rodzinnych i akcje popularyzatorskie francuskojęzycznej części Kanady sprzed 20 lat. Następnie głos należał do dr. hab. Macieja Szukały, który zaprezentował Formy ochrony dokumentacji nieurzędowej $w$ Staatsarchiv Stettin. Przedstawiciel Archiwum Państwowego w Szczecinie omówił działania i wysiłki archiwistów szczecińskich podejmowane od XIX w. na rzecz tytułowej dokumentacji. Elżbieta Rogal z Archiwum Państwowego w Poznaniu w referacie Archiwa prywatne w zasobie Archiwum Państwowego w Poznaniu omówiła zespoły majątkowe oraz spuścizny należące do zasobu AP w Poznaniu. Znaczną część wystąpienia stanowiła 
prezentacja przykładowych materiałów dotyczących omawianego tematu w postaci pokazu slajdów, co wzbogaciło referat.

Tę część zakończyła dyskusja. Wszystkie głosy były ciekawe i oświetlające omawiany problem z innej, czasami zupełnie nowej perspektywy. Najaktywniejszym dyskutantem był m.in. dr Marek Konstankiewicz z UMCS w Lublinie, który mówił o tym, że jeśli archiwa państwowe chcą chronić dziedzictwo proweniencji prywatnej, to muszą przetransformować swoje narzędzia prawne z administracyjnych na cywilne. Doktor Wiśniewski uważał natomiast zupełnie inaczej, twierdząc, że archiwa państwowe muszą wyposażyć się wręcz w narzędzia przymusu: „Nie chodzi o totalitaryzm, ale o zachowanie dziedzictwa narodowego". Ewa Rosowska z NDAP słusznie zapytywała o to, co jest ważniejsze: święte prawo własności czy zachowanie dziedzictwa? Trafnie zauważyła, iż po transformacji ustroju państwa w archiwach wciąż brakuje dokumentacji, która odzwierciedlałaby inne aspekty niż administracja państwowa. Waldemar Chorążyczewski, zaniepokojony długością dyskusji - zbliżała się bowiem pora obiadu - przywołał przykłady Zygmunta Augusta, który w testamencie nakazał spalić szkatułkę z różnymi precjozami, oraz Tomasza Manna, który po prostu spalił swoje dzienniki: „Każdy ma prawo do zapomnienia" - mówił Chorążyczewski.

Trzecią, ostatnią cześć konferencji otworzył dr hab. Paweł Gut ciekawym wystąpieniem na temat archiwów i archiwaliów prywatnych w zasobie Archiwum Państwowego w Szczecinie. Zbiory te można podzielić na: spuścizny naukowców, dokumentację po osobach życia publicznego oraz kolekcje prywatne. I tak pojawiły się w wystąpieniu takie osobistości, jak Piotr Zaręba, pierwszy powojenny prezydent Szczecina, Bogdan Dopierała, wybitny profesor chemii, czy fotograf prasowy, Anatol Wechrter. Obecnie AP w Szczecinie nieustannie poszerza swój zasób o rozmaite archiwa prywatne, które przekazywane są do archiwum w oparciu o umowy zawierające niezbędne klauzule dotyczące przechowywania, reprodukcji, udostępniania i praw autorskich. Ostatnie trzy referaty tej części dotyczyły spraw genealogicznych. Głosy zabrali genealodzy środowiska poznańskiego: Łukasz Bielecki zaprezentował Projekt Poznań - internetowa bazę materiatów metrykalnych z terenu Wielkopolski; Wojciech Jędraszewski omówił program BASIA, naświetlając problem indeksacji zdigitalizowanych materiałów metrykalnych, jako formę crowdsourcingu archiwalnego; Leszek Krajkowski, prezes Towarzystwa Genealogiczno-Heraldycznego w Poznaniu, zaprezentował referat pt. Wykorzystanie źródet z zasobów prywatnych do badań genealogicznych, w którym za- 
warł m.in. Teki Dworzaczka, Archiwum Skowrońskiego z Biblioteki PTPN czy spuścizny Stanisława Karwowskiego i Sławomira Leitgebera z Archiwum PAN w Poznaniu.

Profesor Stryjkowski, zamykając obrady, przypomniał, jak ważna jest tematyka poruszana na konferencji. Trzeba wyrazić nadzieję, że konferencja w Poznaniu doczeka się kontynuacji.

Piotr Bewicz (Uniwersytet Mikołaja Kopernika w Toruniu)

SyMPOZJUM NAUKOWE „KOMPUTERYZACJA I DigitaliZaCJA W ARCHIWACH”

http://dx.doi.org/10.12775/AKZ.2014.014

WW Olsztynie 27-28 października 2014 r. odbyło się sympozjum naukowe poświęcone „Komputeryzacji i digitalizacji w archiwach”. Organizatorami tego przedsięwzięcia byli dr Anna Żeglińska z Uniwersytetu Warmińsko-Mazurskiego w Olsztynie, dr hab. Waldemar Chorążyczewski, prof. Uniwersytetu Mikołaja Kopernika w Toruniu, oraz dr Rafał Leśkiewicz z Instytutu Pamięci Narodowej w Warszawie.

W sympozjum udział wzięli przedstawiciele Naczelnej Dyrekcji Archiwów Państwowych, dyrektorzy i pracownicy archiwów państwowych z Gdańska, Olsztyna, Poznania, Torunia i Warszawy, przedstawiciele Instytutu Pamięci Narodowej, Ministerstwa Obrony Narodowej, archiwów kościelnych oraz przedstawiciele ośrodków kształcących archiwistów z Uniwersytetu Mikołaja Kopernika w Toruniu, Uniwersytetu im. Stefana Kardynała Wyszyńskiego w Warszawie, Uniwersytetu im. Adama Mickiewicza w Poznaniu, Uniwersytetu Marii Curie-Skłodowskiej w Lublinie, Uniwersytetu Warmińsko-Mazurskiego w Olsztynie. Gościem honorowym sympozjum był prof. dr hab. Bohdan Ryszewski.

Uczestnicy oraz zaproszeni specjaliści - prelegenci z zakresu komputeryzacji i digitalizacji archiwów - spotkali się 27 października w pięknej scenerii 